\title{
PENGARUH PENDIDIKAN, PELATIHAN, MOTIVASI DAN PENGALAMAN KERJA TERHADAP KINERJA PERANGKAT DESA DI KECAMATAN MURUNG PUDAK KABUPATEN TABALONG
}

\author{
Edy Rahmanto \\ Sekolah Tinggi Ilmu Ekonomi Pancasetia \\ Jl. Ahmad Yani Km. 5.5 Banjarmasin \\ eddy.bandzema@gmail.com
}

\begin{abstract}
ABSTRAK
Abstact : This study aims to determine how much influence Education, Training, Motivation and Work Experience on the Performance of Village Apparatuses in Murung Pudak Subdistrict, Tabalong Regency partially, simultaneously, and variables that have a dominant influence on the Performance of Village Apparatuses in Murung Pudak District Tabalong District. The method used in this study is a quantitative method, with the population of all village officials as many as 35 respondents and the sampling technique is Saturated Sampling, the research instrument validity test, reliability test and data are tested with multiple linear regression with classic assumptions.The results of this study indicate that the Work Experience Variable partially has a significant effect on the Performance of the Village Apparatus. Education, training, motivation and work experience variables simultaneously affect the performance of village officials. And the dominant variable influencing the performance of village officials in Murung Pudak District, Tabalong Regency is Work Experience.
\end{abstract}

Keywords: Education, Training, Motivation, Work Experience and Motivation

Abstrak : Penelitian ini bertujuan untuk mengetahui seberapa besar pengaruh Pendidikan, Pelatihan, Motivasi dan Pengalaman Kerja Terhadap Kinerja Perangkat Desa di Kecamatan Murung Pudak Kabupaten Tabalong secara parsial, simultan, dan variabel yang berpengaruh dominan terhadap Kinerja Perangkat Desa di Kecamatan Murung Pudak Kabupaten Tabalong. Metode yang digunakan dalam penelitian ini adalah metode kuantitatif, dengan populasi seluruh perangkat desa sebanyak 35 orang sebagai responden dan tekhnik sampling adalah Sampling Jenuh, Instrument penelitian uji validitas, uji reabilitas dan data diuji dengan regresi linier berganda dengan asumsi klasik. Hasil penelitian ini menunjukan bahwa Variabel Pengalaman Kerja secara parsial berpengaruh signifikan terhadap Kinerja Perangkat Desa. Variabel Pendidikan, Pelatihan, Motivasi dan Pengalaman Kerja secara simultan berpengaruh terhadap Kinerja Perangkat Desa. Dan Variabel yang dominan berpengaruh terhadap Kinerja Perangkat Desa di Kecamatan Murung Pudak Kabupaten Tabalong adalah Pengalaman Kerja. Kata kunci : Pendidikan, Pelatihan, Motivasi, Pengalaman Kerja dan Motivasi 


\section{LATAR BELAKANG}

\subsection{Latar Belakang}

Undang - Undang Nomor 6 Tahun 2014 tentang Desa yang didukung dengan Peraturan Pemerintah Nomor 43 Tahun 2014 tentang Peraturan Pelaksanaan Undang-Undang Nomor 6 Tahun 2014 Tentang Desa dan Peraturan Pemerintah Nomor 60 Tahun 2014 tentang Dana Desa yang Bersumber dari APBN, telah memberikan pondasi dasar terkait dengan Penyelenggaraan Pemerintahan Desa, pelaksanaan pembangunan Desa, pembinaan kemasyarakatan Desa, dan pemberdayaan masyarakat Desa berdasarkan Pancasila, Undang- Undang Dasar Negara Republik Indonesia Tahun 1945, Negara Kesatuan Republik Indonesia, dan Bhinneka Tunggal Ika.

Masyarakat yang dinamis telah berkembang dalam berbagai kegiatan yang semakin membutuhkan aparatur pemerintah yang profesional. Seiring dengan dinamika masyarakat dan perkembangannya, kebutuhan akan pelayanan yang semakin kompleks serta pelayanan yang semakin baik, cepat, dan tepat. Aparatur pemerintah yang berada ditengah-tengah masyarakat dinamis tersebut tidak dapat tinggal diam, tetapi harus mampu memberikan berbagai pelayanan yang sesuai dengan kebutuhan masyarakat.

Terjadinya perubahan undang-undang desa menyebabkan terjadinya perubahan sistem dan struktur kepemerintahan di desa. Untuk menghadapi perubahan tersebut Pemerintah Kecamatan Murung Pudak berkewajiban meningkatkan kemampuan aparatur pemerintahannya di berbagai bidang, antara lain peningkatan kemampuan SDM seperti keahlian, pengetahuan dan ketrampilan dengan melalui pendidikan, pelatihan, kursus, magang, seminar/diskusi dan lainlain.

Pemerintahan Kecamatan Mururung Pudak dalam rangka peningkatan mutu dan kualitas SDM, sudah melaksanakan pelatihan penjenjangan dan pelatihan teknis sebagai bentuk dan dukungan agar dapat meningkatkan kinerja kepala desa dalam melaksanakan tugas dan tanggung jawabnya sebagai aparatur pemerintah di desa.

Salah satu upaya yang telah dilakukan Pemerintahan Kecamatan Murung Pudak meningkatkan motivasi, kinerja dan pelayanan kepada masyarakat adalah dengan membuat kebijakan dalam bentuk peraturan dan juga program daerah yang bersenergi dengan pemerintahan desa dengan tujuan diharapkan dapat mendukung dan membantu Pemerintahan Kabupaten Tabalong dalam mempercepat proses pembangunan. Kinerja dalam organisasi merupakan jawaban dari berhasil atau tidaknya tujuan organisasi yang telah ditetapkan. Para pimpinan atau manajer sering tidak memperhatikan kecuali sudah amat buruk atau segala sesuatu jadi serba salah. Terlalu sering para pimpinan atau manajer tidak mengetahui betapa buruknya kinerja telah merosot sehingga organisasi/instansi menghadapi krisis yang serius. Kesan-kesan buruk organisasi yang mendalam berakibat dan mengabaikan tanda-tanda peringatan adanya kinerja yang merosot.

Pada dasarnya kinerja perangkat desa tidak cukup hanya dengan peningkatan pendidikan dan pelatihan saja, tetapi bisa juga dilakukan melalui peningkatan motivasi kepada mereka. Timbulnya motivasi pada diri seseorang tentu oleh adanya suatu kebutuhan hidupnya baik itu kebutuhan primer maupun kebutuhan sekundernya. Jika kebutuhan tersebut dapat terpenuhi, maka seseorang akan giat bekerja sehingga kinerja dapat meningkat.

Kinerja perangkat desa sebagai aparatur pemerintahan desa khususnya yang ada di Kecamatan Murung Pudak tentu dipengaruhi oleh kebutuhan seperti yang dimaksud di atas, dan mereka akan bekerja keras jika pekerjaannya itu dapat memenuhi kebutuhan tersebut. Disamping faktor motivasi juga faktor pengalaman kerja sebagai perangkat desa akan ikut mempengaruhi prestasi kerja (kinerja) dalam pelaksanaan tugas kepemerintahan desanya. Seorang perangkat desa yang sudah lama bekerja sebagai perangkat desa 
akan lebih berpengalaman dibandingkan dengan yang baru bekerja sebagai perangkat desa, dan dengan pengalaman tersebut ia akan mudah melaksanakan tugas kesehariannya sebagai aparatur pemerintahan desa.

\subsection{Rumusan Masalah}

Berdasarkan uraian di atas, dirumuskan masalah sebagai berikut :

a. Apakah pendidikan, pelatihan, motivasi, dan pengalaman kerja berpengaruh secara parsial terhadap kinerja perangkat desa dalam pelaksanaan tugas pemerintahan desa di Kecamatan Murung Pudak Kabupaten Tabalong Provinsi Kalimantan Selatan?

b. Apakah pendidikan, pelatihan, motivasi, dan pengalaman kerja2.1.2 berpengaruh secara simultan terhadap kinerja perangkat desa dalam pelaksanaan tugas pemerintahan desa di Kecamatan Murung Pudak Kabupaten Tabalong Provinsi Kalimantan Selatan?

c. Dari faktor Pendidikan, pelatihan, motivasi dan pengalaman kerja, faktor manakah yang dominan mempengaruhi kinerja perangkat desa?

\section{STUDI LITERATUR}

\subsection{Landasan Teori}

\subsubsection{Pengertian dan Tujuan Penilaian Kinerja}

Kinerja jika dilihat dari asal katanya adalah terjemahan dari kata performance, yang menurut The Scribner-Bantam English Dictionary, terbitan Amerika Serikat dan Canada tahun 1979, berasal dari akar kata "to perform" dengan beberapa "entries" yaitu : 1) melakukan, menjalankan, melaksanakan (to do or carry out, execute), 2) memenuhi atau melaksanakan kewajiban suatu niat atau nazar (to discharge of fulfill;as vow), 3) melaksanakan atau menyem-purnakan tanggung jawab (to execute or complete an understaking), dan 4) melakukan sesuatu yang diharapkan oleh seseorang atau mesin (to do what is expected of a person machine).
Donnely, Gibson, dan Ivancevich dalam Rivai (2005) menyatakan bahwa "Kinerja merujuk kepada tingkat keberhasilan dalam melaksanakan tugas serta kemampuan untuk mencapai tujuan yang telah ditetapkan. Kinerja dinyatakan baik dan sukses jika tujuan yang diinginkan dapat tercapai dengan baik".

Selanjutnya Simamora (2004) menyatakan bahwa "Kinerja mengacu kepada kadar pencapaian tugas-tugas yang membentuk sebuah pekerjaan pegawai". Sedangkan Soeprihanto (2001) menyatakan bahwa "Kinerja atau prestasi kerja adalah hasil kerja seseorang selama periode tertentu dibandingkan dengan berbagai kemungkinan, misalnya standar, target/sasaran".

\section{Pendidikan}

Pendidikan merupakan proses pembelajaran melalui proses dan prosedur yang sistematis yang terorganisir baik teknis maupun manajerial yang berlangsung dalam waktu yang relatif lama.

Menurut Zainun (2005) pendidikan pada dasarnya dimaksudkan untuk mempersiapkan SDM sebelum memasuki pasar kerja. Dengan pengetahuan yang diperoleh dari pendidikan dalam proporsi tertentu diharapkan sesuai dengan syaratsyarat yang dituntut oleh suatu pekerjaan.

Selanjutnya Soeprihanto (2001) menyatakan bahwa "Pendidikan mempunyai fungsi sebagai penggerak sekaligus pemacu terhadap potensi kemampuan SDM dalam meningkatkan prestasi kerjanya, dan nilai kompetensi seorang pekerja dapat dipupuk melalui program pendidikan, pengembangan dan pelatihan".

Menurut Simamora (2004), pertanyaan yang harus dihadapi oleh organisasi bukan lagi apakah akan melakukan investasi bagi pengembangan sumber daya manusia yang dimiliki, melainkan berapa besar investasi yang harus dibuat. Dari pertanyaan tersebut menunjukkan bahwa pengembangan sumber daya manusia mutlak diperlukan bagi organisasi yang terus berkembang sejalan dengan perkembangan dalam masyarakat. 
Para pegawai yang sudah berpengalamanpun selalu memerlukan pengetahuan, keterampilan dan kemampuan, karena selalu ada cara yang lebih baik untuk meningkatkan produktivitas kerja. Peningkatan, pengembangan dan pembentukan tenaga kerja dapat dilakukan melalui upaya pembinaan, pendidikan dan latihan (Hamalik, 2006).

Pendidikan merupakan upaya untuk mengembangkan sumber daya manusia, terutama untuk mengembangkan kemampuan intelektual dan kepribadian (Notoatmojo, 2003). Pendidikan berkaitan dengan mempersiapkan calon tenaga yang diperlukan oleh suatu instansi atau organisasi sehingga cara penekanannya pada kemampuan kognitif, afektif dan psychomotor. Pendidikan merupakan proses pembelajaran melalui proses dan prosedur yang sistematis dan terorganisir baik teknis maupun manajerial yang berlangsung dalam waktu yang relatif lama. Menurut Soeprihanto (2001) dalam pengembangan sumber daya (human resource development) bahwa nilai-nilai kompetensi seseorang pekerja dapat dipupuk melalui program pendidikan, pengembangan atau pelatihan yang berorientasi pada tuntutan kerja aktual dengan penekanan pada pengembangan skill, knowledge dan ability yang secara signifikan akan dapat memberi standar perilaku dalam sistem dan proses kerja yang diterapkan.

Pendidikan dengan berbagai programnya mempunyai peranan penting dalam proses memperoleh dan meningkatkan kualitas kemampuan profesional individu. Melalui pendidikan seseorang dipersiapkan untuk memiliki bekal agar siap tahu, mengenal dan mengembangkan metode berpikir secara sistematik agar dapat memecahkan masalah yang akan dihadapi dalam kehidupan dikemudian hari (Sedarmayanti, 2005).

\subsubsection{Teori Tentang Pelatihan 2.1.3.1. Pengertian dan Manfaat Pelatihan}

Pelatihan merupakan suatu usaha mengurangi atau menghilangkan terjadinya kesenjangan antara kemampuan pegawai dengan yang dikehendaki organisasi. Usaha tersebut dilakukan melalui peningkatan kemampuan kerja yang memiliki pegawai dengan cara menambah pengetahuan dan ketrampilan serta merubah sikap. Pegawai merupakan kekayaan organisasi yang paling berharga, karena dengan segala potensi yang dimilikinya, pegawai dapat terus dilatih dan dikembangkan, sehingga dapat lebih berkarya guna, prestasinya menjadi semakin optimal untuk mencapai tujuan organisasi.

Menurut Bernardin dan Russell dalam Gomes (2000) menyatakan bahwa "Pelatihan adalah setiap usaha untuk memperbaiki performan pegawai pada pekerjaan tertentu yang sedang menjadi tanggung jawabnya, atau satu pekerjaan yang ada kaitannya dengan pekerjaannya. Pelatihan lebih berkaitan dengan peningkatan keterampilan pegawai yang sudah menduduki suatu pekerjaan atau tugas tertentu sehingga lebih menekankan pada keterampilan (skill). Pelatihan merupakan cara terpadu yang diorientasikan pada tuntutan kerja aktual, dengan penekanan pada pengembangan skill, knowledge dan ability".

Soeprihanto (2001) menyatakan bahwa "Pelatihan adalah kegiatan untuk memperbaiki kemampuan pegawai dengan cara meningkatkan pengetahuan dan ketrampilan operasional dalam menjalankan suatu pekerjaan".

\subsubsection{Teori Tentang Motivasi 2.1.4.1 Pengertian dan Faktor-faktor Motivasi}

Motivasi berasal dari kata Latin "movere" yang berarti dorongan atau menggerakkan. Motivasi (motivation) dalam manajemen hanya ditujukan untuk sumber daya manusia umumnya dan bawahan khususnya. Motivasi mempersoalkan bagaimana caranya mengarahkan daya dan potensi bawahan agar mau bekerjasama secara produktif berhasil mencapai dan mewujudkan tujuan yang telah ditentukan (Hasibuan, 2000). Sperling dalam Mangkunegara (2006) menyatakan 
bahwa "Motivasi merupakan sebagai suatu kecenderungan untuk beraktivitas, mulai dari dorongan dalam diri (drive) dan diakhiri dengan penyesuaian diri”.

Sedangkan Mangkunegara (2006) menyatakan bahwa "Motivasi terbentuk dari sikap (attitude) seorang pegawai dalam menghadapi situasi (situation) kerja. Motivasi merupakan kondisi yang menggerakkan diri pegawai yang terarah untuk mencapai tujuan organisasi (tujuan kerja)".

Selanjutnya Sedarmayanti (2005) menyatakan bahwa "Motivasi dapat diartikan sebagai suatu daya pendorong (driving force) yang menyebabkan orang berbuat sesuatu atau yang diperbuat karena takut akan sesuatu. Misalnya ingin naik pangkat atau naik gaji, maka perbuatannya akan menunjang pencapaian keinginan tersebut. Yang menjadi pendorong dalam hal tersebut adalah bermacam-macam faktor diantaranya faktor ingin lebih terpandang diantara rekan kerja atau lingkungan dan kebutuhannya untuk berprestasi.

Berdasarkan pendapat dari para ahli manajemen sumber daya manusia di atas dapat disimpulkan bahwa tidak ada motivasi jika tidak dirasakan adanya kebutuhan dan kepuasan serta ketidakseimbangan. Rangsangan terhadap hal termaksud akan menumbuhkan tingkat motivasi, dan motivasi yang telah tumbuh akan merupakan dorongan untuk mencapai tujuan pemenuhan kebutuhan atau pencapaian keseimbangan. Motivasi merupakan suatu dorongan kebutuhan dari dalam diri pegawai yang perlu dipenuhi agar pegawai tersebut dapat menyesuaikan diri terhadap lingkungannya, sedangkan motivasi adalah kondisi yang menggerakkan pegawai agar mampu mencapai tujuan dari motifnya.

\subsubsection{Pengalaman Kerja}

Pada awalnya orang bekerja pada suatu organisasi atau lembaga dengan tugas atau pekerjaan yang belum pernah ia tangani tentu disertai perasaan yang was-was atau bertanya-tanya. Tetapi setelah dikerjakan berulang kali pekerjaan yang sama maka ia akan terbiasa dan perasaan kaku menjadi hilang. Hal ini cocok dengan pepatah lama, bahwa bisa karena biasa.

Faktor kemampuan seseorang tidak cukup hanya dilihat dari segi pendidikan dan pelatihan saja, namun bisa juga dilihat dari segi pengalaman atau pengalaman kerja seseorang selama bekerja pada oraganisasi/lembaga tertentu.

Menurut Wibowo (2007) bahwa "Pengalaman merupakan salah satu faktor yang ikut mempengaruhi kinerja seseorang didalam melaksanakan tugas guna pencapaian tujuan organisasinya".

Pengalaman kerja sebagai perangkat desa dalam suatu pemerintahan desa akan berpengaruh terhadap kinerja kepemerintahan desa. Dengan dibekali banyak pengalaman maka kemungkinan untuk mewujudkan prestasi atau kinerja yang baik cukup meyakinkan, dan sebaliknya bila tidak cukup berpengalaman didalam melaksanakan tugasnya seseorang akan besar kemungkinan mengalami kegagalan.

\subsection{Hasil Penelitian Terdahulu}

Sejauh ini penelitian dengan pembahasan pengaruh Pendidikan, Pelatihan, Motivasi dan Pengalaman Kerja terhadap Kinerja Perangkat Desa di Kecamatan Murung Pudak Kabupaten Tabalong belum pernah dilakukan. Oleh karena itu merupakan penelitian yang original, bukan merupakan penelitian ulang.

Namun demikian yang berkaitan dengan penelitian tentang kinerja (prestasi kerja) adalah sebagai berikut :

1. Muhammad Noor Program Pasca Sarjana, Program Study Magister Manajamen Sekolah Tinggi Ilmu Ekonomi Pancasetia Banjarmasin 2019 melakukan penelitian dengan judul "Pengaruh Pendidikan, Pelatihan, dan Pemberian Insentif Terhadap Kinerja Pegawai Dinas Kesehatan Kabupaten Balangan”.

Kesimpulan dari penelitian tersebut adalah :

a. Pendidikan, Pelatihan dan Pemberian Insentif berpengaruh secara simultan 
terhadap Kinerja Dinas Kesehatan Kabupaten Balangan.

b. Pendidikan, Pelatihan dan Pemberian Insentif berpengaruh secara parsial terhadap Kinerja Dinas Kesehatan Kabupaten Balangan.

c. Variabel yang berpengaruh dominan terhadap Kinerja Dinas Kesehatan Kabupaten Balangan adalah Pelatihan.

2. Ahmad Fikri Program Pasca Sarjana, Program Study Magister Manajamen Sekolah Tinggi Ilmu Ekonomi Pancasetia Banjarmasin 2012 melakukan penelitian dengan judul "Pengaruh Pendidikan, Pelatihan, Motivasi Kerja Terhadap Kemampuan Kerja dan Kinerja Pegawai Sekretariat Daerah Kabupaten Barito Timur".

Kesimpulan dari penelitian tersebut adalah : a. Pendidikan dan Pelatihan berpengaruh secara langsung dan signifikan terhadap kemampuan kerja pegawai Sekretariat Daerah Kabupaten Barito Timur.

b. Motivasi Kerja berpengaruh secara langsung dan signifikan terhadap kemampuan kerja pegawai Sekretariat Daerah Kabupaten Barito Timur.

c. Pendidikan dan Pelatihan berpengaruh secara langsung dan signifikan terhadap kinerja pegawai Sekretariat Daerah Kabupaten Barito Timur.

d. Motivasi kerja berpengaruh secara langsung dan signifikan terhadap kinerja pegawai Sekretariat Daerah Kabupaten Barito Timur.

e. Kemampuan kerja berpengaruh secara langsung dan signifikan terhadap kinerja pegawai Sekretariat Daerah Kabupaten Barito Timur.

3. Atmo Program Pasca Sarjana, Program Study Magister Manajamen Sekolah Tinggi Ilmu Ekonomi Pancasetia Banjarmasin 2012 melakukan penelitian dengan judul "Pengaruh Pendidikan Pelatihan, Motivasi dan Pengalaman Kerja Terhadap Kinerja Dinas Pertanian dan Peternakan Kabupaten Pulang Pisau”.
Kesimpulan dari penelitian tersebut adalah

a. Dari hasil penelitian terlihat bahwa ketiga variable tentang Pendidikan Pelatihan $\left(\mathrm{X}_{1}\right)$, Motivasi $\left(\mathrm{X}_{2}\right)$ dan Pengalama Kerja $\left(\mathrm{X}_{3}\right)$ berpengaruh signifikan terhadap Kinerja (Y) Dinas Pertanian dan Peternakan Kabupaten Pulang Pisaau secara parsial.

b. Ketiga Variabel indevenden secara simultan bersama-sama berpengaruh signifikan terhadap kinerja.

c. Hasil penelitian menyatakan bahwa variable yang berpengaruh dominan terhadap Kinerja adalah variable Pengalaman Kerja $\left(\mathrm{X}_{3}\right)$

\section{METODE PENELITIAN}

\subsection{Lokasi dan Jadwal Penelitian}

Penelitian ini dilakukan di wilayah Kecamatan Murung Pudak Kabupaten Tabalong Provinsi Kalimantan Selatan, yang terdiri dari 5 (lima) desa yaitu Desa Kapar, Desa Masukau, Desa Kasiau Raya, Desa Kasiau dan Desa Maburai.

Penelitian ini dilaksanakan selama 1 Semester( 6 bulan ) yaitu terlihat pada tabel dibawah ini :

Tabel 4.7

Jadwal Penelitian Penulis

\begin{tabular}{|c|c|c|c|c|c|c|c|}
\hline \multirow{2}{*}{ No. } & \multirow{2}{*}{ Uraian Kegiatan } & \multicolumn{6}{|c|}{ Bulan } \\
\hline & & 1 & 2 & 3 & 4 & 5 & 6 \\
\hline 1. & $\begin{array}{c}\text { Survey } \\
\text { Lapangan }\end{array}$ & $\sqrt{ }$ & & & & & \\
\hline 2. & Penentuan Judul & & $\sqrt{ }$ & & & & \\
\hline 3. & $\begin{array}{c}\text { Pembuatan } \\
\text { Proposal }\end{array}$ & & & $\sqrt{ }$ & & & \\
\hline 4. & $\begin{array}{c}\text { Pengumpulan } \\
\text { data-data }\end{array}$ & & & & $\sqrt{ }$ & & \\
\hline 5. & Bimbingan & & & & & $\sqrt{ }$ & \\
\hline 6. & $\begin{array}{c}\text { Penulisan Hasil } \\
\text { Akhir }\end{array}$ & & & & & & $\sqrt{ }$ \\
\hline
\end{tabular}

Sumber : Diolah Penulis 


\subsection{Populasi dan Sampel}

\section{Populasi}

Menuruts Sugiyono (2010:90) pengertian populasi adalah wilayah generalisasi yang terdiri atas objek/subjek yang mempunyai kualitas dan karakteristik tertentu yang ditetapkan oleh peneliti untuk dipelajari dan kemudian ditarik kesimpulannya. Menurut Arikunto (2006:130) adalah keseluruhan subjek penelitian. Apabila seseorang ingin meneliti semua elemen yang ada dalam wilayah penelitian, maka penelitiannya merupakan penelitian populasi. Populasi dalam penelitian ini adalah seluruh perangkat desa pada Kecamatan Murung Pudak Kabupaten Tabalong sebanyak 35 orang.

\section{Sampel}

Apabila subjek penelitian kurang dari 100 orang lebih baik diambil semua sehingga penelitiannya merupakan penelitian populasi. Tetapi jika subjeknya besar, dapat diambil 10-15\% atau 20-25 \% (Arikunto 2006-134) Karena jumlah polulasi relatif sedikit, maka semua populasi dijadikan sampel yaitu sebanyak 35 orang. Adapun metode penetapan sampel adalah sensus, yaitu jumlah keseluruhan populasi dijadikan sampel.

\subsection{Definisi Operasional Variabel}

Defenisi operasional adalah sebuah batasan-batasan yang diberikan terhadap variabel agar variabel tersebut dapat diukur. Sedangkan variabel adalah segala sesuatu yang akan menjadi objek pengamatan penelitian juga sebagai faktor-faktor yang berperan dalam peristiwa atau gejala yang akan diteliti. Variabel dalam penelitian ini terdapat dua variabel bebas $(\mathrm{X})$ dan satu variabel terikat (Y).

4.2.1 Variabel bebas atau independen variabel (Xi)

Variabel ini sering disebut sebagai variabel stimulus. Dalam bahasa Indonesia sering disebut sebagai variabel bebas. Variabel bebas adalah variabel yang mempengaruhi atau yang menjadi sebab perubahannya atau timbulnya variabel dependen (terikat) Variabel bebas dalam penelitian ini meliputi Tingkat Pendidikan (X1), Pelatihan (X2), Motivasi (X3), dan Pengalaman Kerja (X4)

\subsection{Teknik Pengumpulan Data}

Pengumpulan data Primer dalam penelitian ini dilakukan melalui penyebaran kuisioner yang telah disiapkan kepada seluruh responden (Kepala Desa). Untuk data primer tersebut dilakukan observasi terhadap pelaksanaan tugas Kepala Desa serta diwawancarai langsung pada obyek penelitian.

Pengumpulan data sekunder dalam penelitian ini dilakukan melalui lembaga atau instansi terkait seperti melalui Kantor Statistik, Kantor DPMPD, Kantor Camat dan Kantor Desa dengan mencatat data-data yang sudah terdokumen dalam laporan, papan data dan lain-lain.

\subsection{Teknik Analisis Data}

Teknik analisis data yang digunakan dalam penelitian ini adalah analisis regresi linear berganda dengan menggunakan program SPSS (Statistical Package for Social Science). Analisis ini dilakukan dengan beberapa tahapan sebagai berikut:

Teknik analisis data yang digunakan dalam penelitian ini adalah analisis regresi linear berganda dengan menggunakan program SPSS (Statistical Package for Social Science). Analisis ini dilakukan dengan beberapa tahapan sebagai berikut: 


\section{Analisis Deskriptif}

Deskriptif data merupakan suatu metode atau cara-cara yang digunakan untuk meringkas dan menyimpulkan data. Deskriptif digunakan untuk menganalisa data dengan cara mendeskripsikan atau menggambarkan data yang telah terkumpul sebagaimana adanya tanpa bermaksud membuat kesimpulan yang berlaku umum ataupun generalisasi.

\section{Uji Kualitas Data \\ a. Uji Validitas}

Untuk mendukung analisis regresi dilakukan uji validitas dan reabilitas. Uji validitas dalam penelitian ini digunakan untuk menguji kevalidan kuesioner. Validitas menunjukkan sejauh mana ketetapan dan kecermatan suatu alat ukur dalam melakukan kecermatan fungsi alat ukurnya. Pengujian menggunakan 2 sisi dengan taraf signifikan 0.05 jika $r$ hitung > $r$ tabel maka instrumen atau item- item pernyataan berkorelasi signifikan terhadap skor total (dinyatakan valid), dan sebaliknya jika $r$ hitung $<\mathrm{r}$ tabel dinyatakan tidak valid.

\section{b. Uji Reliabilitas}

Uji reliabilitas digunakan untuk mengetahui konsistensi alat ukur, apakah alat pengukur yang digunakan dapat diandalkan dan tetap konsisten jika pengukuran tersebut diulang. Adapun cara yang digunakan untuk menguji reliabilitas kuesioner dalam penelitian ini adalah menggunakan rumus koefisien Alpha Cronbach. Untuk mengetahui kuesioner tersebut sudah reliable akandilakukan pengujian reabilitas kuesioner dengan bantuan komputer program SPSS.

Tabel 4.6 : Tingkat Reliabilitas Berdasarkan Nilai Alpha

Berdasarkan tabel di atas kriteria penelitian uji reliabilitas adalah: Apabila hasil koefisien Alpha lebih besar dari taraf signifikansi $60 \%$ atau 0.6 maka kuesioner tersebut reliable.

\section{Uji Asumsi Klasik \\ a. Uji Normalitas}

Uji normalitas data bertujuan untuk mengetahui apakah distribusi sebuah data mengikuti atau mendekati distribusi normal. Uji normalitas ini memiliki dua cara untuk menguji apakah distribusi normal atau tidak, yaitu melalui pendekatan

\begin{tabular}{|c|c|}
\hline Alpha & Tingkat Reliabilitas \\
\hline 0,00 s.d 0,20 & Kurang Reliabel \\
\hline 0,20 s.d 0,40 & Agak Reliabel \\
\hline 0,40 s.d 0,60 & Cukup Reliabel \\
\hline 0,60 s.d 0,80 & Reliabel \\
\hline 0,80 s.d 1,00 & Sangat Reliabel \\
\hline
\end{tabular}

histogram dan pendekatan grafik. Pada pendekatan histogram data berdistribusi normal apabila distribusi data tersebut tidak melenceng kekiri atau melenceng kekanan. Pada pendekatan grafik data berdistribusi normal apabila titik mengikuti data di sepanjang garis diagonal.

\section{b. Uji Multikolonieritas}

Uji multikolonieritas bertujuan untuk menguji apakah model regresi ditemukan adanya korelasi antar variabel bebas (independen). Salah satu cara untuk mendeteksi multikolinearitas adalah dengan melihat VIF dan tolerance.

Jika nilai VIF < 10 dan tolerance $>0,1$ maka dapat dikatakan tidak ada masalah multikolinearitas. Jika nilai VIF > 10 dan tolerance $<0,1$ maka dapat dikatakan ada masalah multikolinearitas.

\section{c. Uji Heteroskedastisitas}

Uji ini bertujuan untuk mengetahui apakah dalam model regresi terjadi ketidaksamaan varians dan residual pengamatan yang lain dengan dasar pengambilan keputasan adalah sebagai berikut.

1) Jika ada data yang membentuk pola tertentu, seperti titik-titik yang membentuk pola tertentu dan teratur (bergelombang, melebar kemudian menyamping) maka telah terjadi heteroskedastisitas.

2) Jika tidak ada pola yang jelas serta titik-titik menyebar di atas dan di bawah angka 0 maka tidak terjadi heteroskedastisitas. 


\section{Uji Regresi Linear Berganda}

Uji persamaan regresi yang digunakan dalam penelitian ini adalah uji regresi linear berganda apabila dalam persamaan garis regresi tercakup lebih dari dua variabel baik itu variable bebas $\mathrm{X}$ maupun variabel tidak bebas Y. Adapun rumus regresi linear berganda adalah:

$\mathrm{K}=\mathrm{a}+\mathrm{b} 1 \mathrm{TP}+\mathrm{b}_{2} \mathrm{P}+\mathrm{b}_{3} \mathrm{M}+\mathrm{b}_{4} \mathrm{PK}+$ e

Dimana:

$$
\begin{array}{ll}
\mathrm{K} & =\text { Kinerja }(\mathrm{Y}) \\
\mathrm{TP} & =\text { Tingkat Pendidikan }(\mathrm{X} 1) \\
\mathrm{P} & =\text { Pelatihan }\left(\mathrm{X}_{2}\right) \\
\mathrm{M} & =\text { Motivasi }\left(\mathrm{X}_{3}\right) \\
\mathrm{PK} & =\text { Pengalaman Kerja }(\mathrm{X} 4) \\
\mathrm{a} & =\text { Konstanta } \\
\mathrm{b} 1, \mathrm{~b} 2 & =\text { Koefisien regresi } \\
\mathrm{e} & =\text { error term }
\end{array}
$$

\section{Uji Statistik}

\section{a. Uji t}

Uji t digunakan untuk mengetahui ada atau tidaknya pengaruh masing- masing variabel independen secara parsial terhadap variabel dependen yang diuji pada tingkat signifikan 0,05 . Uji t bertujuan untuk mengetahui apakah variabel- variabel bebas yang digunakan dalam model persamaan regresi, kriteria keputusannya adalah sebagai berikut. Berdasarkan nilai t hitung dan t table: 1) Apabila thitung $>$ ttabel atau tstatistic $<0,05$, maka $\mathrm{Ho}_{\mathrm{o}}$ ditolak dan $\mathrm{Ha}$ diterima, berarti terdapat pengaruh dari variabel bebas terhadap variable terikat. Apabila thitung < tabel atau tstatistik > 0,05, maka $\mathrm{Ha}$ ditolak dan Ho diterima, berart tidak terdapat pengaruh dari variable bebas terhadap variabel terikat.

\section{b. Uji F}

Uji $\mathrm{F}$ bertujuan untuk mengetahui apakah variabel bebas yang digunakan dalam model regresi secara simultan yang mampu menjelaskan variabel terikatnya. Kriteria keputusannya sebagai berikut:

1) Apabila Fhitung $>$ Ftabel atau Fstatistic < 0,05 maka $\mathrm{H}_{\mathrm{O}}$ ditolak dan $\mathrm{Ha}_{\mathrm{a}}$ diterima, berarti terdapat pengaruh yang signifikan antara variabel bebas terhadap variable terikat.

2) Apabila Fhitung $<$ Ftabel atau Fstatistic $>0,05$ maka $\mathrm{Ha}$ ditolak dan Ho diterima, berarti tidak ada pengaruh antara variabel bebas terhadap variabel terikat.

\section{c. Uji Koefisien Determinasi $\left(\mathbf{R}^{\mathbf{2}}\right)$}

Bertujuan untuk mengetahui kekuatan variabel bebas (independent variabel) menjelaskan variabel terikat (dependent variabel). Dengan kata lain, koefisien determinasi dilakukan untuk melihat seberapa besar kemampuan variabel independen secara bersama mampu memberi penjelasan terhadap variabel dependen.

Adapun rumus koefisien determinasi adalah sebagai berikut:

$$
\mathrm{KD}=\mathbf{r} \times 100 \%
$$

Keterangan:

$$
\begin{aligned}
& \mathrm{KD} \quad=\text { Koefisien } \\
& \text { Determinasi } \\
& \mathrm{R} \quad=\text { Koefisien Korelasi }
\end{aligned}
$$

\section{HASIL PENELITIAN DAN PEMBAHASAN}

\subsection{Analisis Hasil Penelitian}

\subsubsection{Uji Validitas}

Adapun hasil uji validitas instrumen penelitian dapat dilihat

Tabel 5.11 pada table 5.1 dibawah ini :

Rekapitulasi Hasil Uji Validitas Instrumen Penelitian

\begin{tabular}{|c|c|c|c|}
\hline Variabel & Item & R & Keterangan \\
\hline Pendidikan (X1) & X.1.1 & 0,746 & Valid \\
& X1.2 & 0,602 & Valid \\
& X1.3 & 0,549 & Valid \\
& X1.4 & 0,481 & Valid \\
& X1.5 & 0,403 & Valid \\
& X1.6 & 0,575 & Valid \\
\hline Pelatihan (X2) & X2.1 & 0,925 & Valid \\
& X2.2 & 0,804 & Valid \\
& X2.3 & 0,726 & Valid \\
& X2.4 & 0,456 & Valid \\
& X2.5 & 0,830 & Valid \\
& X2.6 & 0,694 & Valid \\
\hline Motivasi (X3) & X3.1 & 0,738 & Valid \\
& X3.2 & 0,519 & Valid \\
& X3.3 & 0,590 & Valid \\
& X3.4 & 0,687 & Valid \\
& X3.5 & 0,801 & Valid \\
\hline Pengalaman & X3.1 & 0,686 & Valid \\
\hline
\end{tabular}




\begin{tabular}{|l|l|l|l|}
\hline Kerja (X4) & X4.2 & 0,755 & Valid \\
& X4.3 & 0,703 & Valid \\
& X4.4 & 0,675 & Valid \\
& X4.5 & 0,748 & Valid \\
& X4.6 & 0,788 & Valid \\
& X4.7 & 0,816 & Valid \\
\hline Kinerja (Y) & Y.1 & 0,757 & Valid \\
& Y.2 & 0,639 & Valid \\
& Y.3 & 0,753 & Valid \\
& Y.4 & 0,560 & Valid \\
& Y.5 & 0,578 & Valid \\
& Y.6 & 0,835 & Valid \\
\hline
\end{tabular}

Dari tabel 5.11 diatas dapat dilihat pada uji validitas semua pertanyaan kuesioner memiliki nilai korelasi > 0,3 maka dapat di nyatakan semua pertanyaan kuesioner dalam penelitian ini adalah valid.

\subsubsection{Uji Reliabilitas}

Adapun hasil uji validitas dan reliabilitas instrument penelitian dapat dilihat pada tabel 5.12 dibawah ini.

Tabel 5.12

Rekapitulasi Hasil Uji Reliabilitas Instrumen

Penelitian

\begin{tabular}{|l|c|c|}
\hline \multicolumn{1}{|c|}{ Variabel } & A & Keterangan \\
\hline Pendidikan (X1) & 0,716 & Reliabel \\
\hline Pelatihan (X2) & 0,785 & Reliabel \\
\hline Motivasi (X3) & 0,765 & Reliabel \\
\hline $\begin{array}{l}\text { Pengalaman Kerja } \\
\text { (X4) }\end{array}$ & 0,782 & Reliabel \\
\hline Kinerja (Y) & 0,765 & Reliabel \\
\hline
\end{tabular}

Sumber : Lampiran 3

Dari tabel 5.12 diatas dapat dilihat pada Uji Reliabilitas berdasarkan hasil Uji Reliabilitas semua instrumen dapat diterima karena Alpha Cronbach > 0,6 maka dapat disimpulkan bahwa semua pertanyaan kuesioner adalah reliabel (dapat diandalkan atau dipercaya)

\subsubsection{Uji Asumsi Klasik}

\section{a. Uji Heteroskedastisitas}

Utuk mengetahui ada atau tidaknya gejala heteroskedastisitas adalah dengan melihat ada tidaknya pola tertentu pada grafik scatter plot.

Output SPSS Versi 23.0 pada gambar scatterplot menunjukkan penyebaran titiktitik data sebagai berikut :

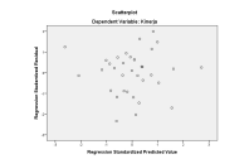

Sumber Lampiran : 3

Berdasarkan output scatterplots diatas diketahui bahwa :

1. Titik - titik data penyebar diatas dan dibawah atau disekitar angka 0 . 2. Titik - titik tidak mengumpul hanya diatas atau dibawah saja.

3. Penyebaran titik-titik data tidak membentuk pola bergelombang melebar kemudian menyempit dan melebar kembali.

4. Penyebaran titik-titik data tidak berpola.

Dengan demikian berdasarkan gambar 5.2 diatas dapat simpulkan bahwa model path analisis dalam penelitian ini terbebas dari heteroskedastisitas dan layak digunakan dalam penelitian karena titik-titik data tidak mengumpul hanya diatas atau dibawah saja dan penyebaran titik-titik data tidak membentuk pola tertentu.

\section{b. Uji Normalitas}

Dengan melihat grafik normal P-Plot dibawah ini, maka terlihat bahwa titik-titik menyebar di sekitar garis diagonal, serta penyebarannya mengikuti arah garis diagonal, grafik tersebut menunjukkan bahwa model regresi layak dipakai karena memenuhi asumsi normalitas. 


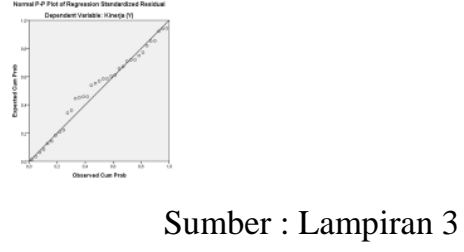

Berdasarkan gambar 5.3 diatas maka dapat disimpulkan bahwa model regresi berganda dalam penelitian ini tidak ada masalah dalam pengujian normalitas dan layak digunakan dalam penelitian karena titik-titik menyebar disekitar garis diagonal, serta penyebarannya mengikuti garis diagonal, maka grafik tersebut menunjukkan bahwa model regresi layak dipakai karena memenuhi asumsi normalitas.

\section{c. Uji Multikolonieritas}

Untuk mengetahui ada tidaknya multikolonieritas antar variabel, dapat dilihat dari Vairabel Inflation Factor (VIF) dan nilai Tolerance dari masingmasing variabel bebas terhadap variabel terikat perbandingan nilai VIF dan Tol dapat dilihat pada tabel 5.13 dibawah ini : Tabel 5.13

Perbandingan Nilai Variabel Inflation Factor (VIF) dan Nilai Tolerance

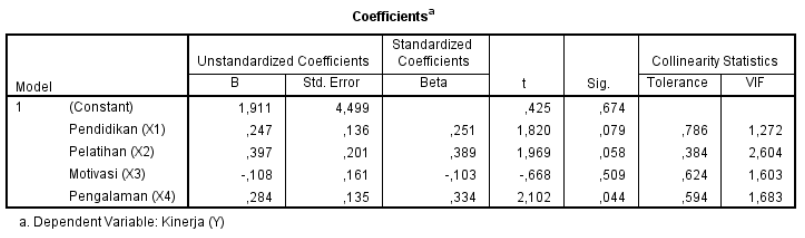

Sumber : Lampiran 3

Dari tabel 5.13 diatas dapat disimpulkan bahwa hasil uji multikolonieritas melalui variabel Variable Inflation Factor (VIF) pada hasil outpus SPSS 23.0 model regresi ini bebas dari masalah Multikolonieritas karena masing-masing variabel independen memiliki VIF kurang dari $<10$

\subsubsection{Analisis Regresi Berganda Variabel Pendidikan (X1), Pelatihan (X2), Motivasi (X3), dan Pengalaman (X4) terhadap Kinerja (Y)}

Tabel 5.14

Rekapitulasi Analisis Regresi Linear Berganda Pengaruh Pendidikan (X1), Pelatihan (X2), Motivasi (X3), dan Pengalaman Kerja (X4) terhadap Kinerja (Y) Perangkat Desa di Kecamatan Murung Pudak Kabupaten Tabalong

\begin{tabular}{|c|c|c|c|c|c|}
\hline $\begin{array}{c}\text { Variab } \\
\text { el }\end{array}$ & $\begin{array}{c}\text { Koef } \\
\text { isien } \\
\text { Regr } \\
\text { esi } \\
\text { (bi) }\end{array}$ & $\begin{array}{c}\mathrm{t} \\
\text { hit } \\
\text { un } \\
\mathrm{g}\end{array}$ & $\begin{array}{c}\mathrm{t} \\
\mathrm{ta} \\
\mathrm{be} \\
1\end{array}$ & $\begin{array}{c}\mathrm{Be} \\
\text { ta }\end{array}$ & $\begin{array}{c}\mathrm{Si} \\
\mathrm{g}\end{array}$ \\
\hline $\begin{array}{l}\text { Konsta } \\
\text { nta }\end{array}$ & $\begin{array}{c}1,91 \\
1 \\
\end{array}$ & & & & \\
\hline $\begin{array}{l}\text { Pendid } \\
\text { ikan } \\
(\mathrm{X} 1)\end{array}$ & $\begin{array}{c}0,24 \\
7\end{array}$ & $\begin{array}{l}1,8 \\
20\end{array}$ & $\begin{array}{c}2, \\
04 \\
2 \\
\end{array}$ & $\begin{array}{c}0 \\
25 \\
1 \\
\end{array}$ & $\begin{array}{c}0, \\
07 \\
9 \\
\end{array}$ \\
\hline $\begin{array}{l}\text { Pelatih } \\
\text { an } \\
(\mathrm{X} 2)\end{array}$ & $\begin{array}{c}0,39 \\
7\end{array}$ & $\begin{array}{l}1,9 \\
69\end{array}$ & $\begin{array}{c}2, \\
04 \\
2 \\
\end{array}$ & $\begin{array}{c}0, \\
38 \\
9 \\
\end{array}$ & $\begin{array}{c}0, \\
05 \\
8 \\
\end{array}$ \\
\hline $\begin{array}{l}\text { Motiva } \\
\text { si (X3) }\end{array}$ & $\begin{array}{c}- \\
0,10 \\
8\end{array}$ & $\begin{array}{c}- \\
, 66 \\
8\end{array}$ & $\begin{array}{c}2, \\
04 \\
2\end{array}$ & $\begin{array}{c}- \\
0 \\
10 \\
3\end{array}$ & $\begin{array}{c}0, \\
50 \\
9\end{array}$ \\
\hline $\begin{array}{l}\text { Pengal } \\
\text { aman } \\
\text { Kerja } \\
(\mathrm{X} 4)\end{array}$ & $\begin{array}{c}0,28 \\
4\end{array}$ & $\begin{array}{l}2,1 \\
02\end{array}$ & $\begin{array}{c}2, \\
04 \\
2\end{array}$ & $\begin{array}{c}0 \\
33 \\
4\end{array}$ & $\begin{array}{c}0, \\
04 \\
4\end{array}$ \\
\hline $\begin{array}{l}\text { Konstanta } \\
1,911\end{array}$ & & \multicolumn{4}{|c|}{ F hitung $=9,205$} \\
\hline $\begin{array}{l}\text { Multiple } \\
0,742\end{array}$ & $\mathrm{R}=$ & \multicolumn{4}{|c|}{$\mathrm{F}$ tabel $=2,900$} \\
\hline $\begin{array}{l}\text { R square } \\
0,551\end{array}$ & $\left.\mathrm{R}^{2}\right)=$ & & , 000 & & \\
\hline
\end{tabular}

Sumber : Lampiran 3

Pada tabel 5.14 dapat dilihat $\mathrm{R}$ square sebesar 0,551 yang berarti besarnya sumbangan seluruh variabel bebas terhadap variabel terikatnya adalah $55,1 \%$ sedangkan sisanya $44,9 \%$ dijelaskan oleh sebab faktor lain diluar penelitian ini.

Berdasarkan tabel 5.14 diperoleh persamaan regresi sebagai berikut :

$Y=1,911 X 1+0,247$ X2 +0,397 X3 + -0,108 $\mathrm{X} 4+$ ie 
Adapun penjelasan dari regresi diatas adalah sebagai berikut :

1. Konstanta bernilai 1,911, berarti jika nilai variabel pendidikan, pelatihan, 'motivasi dan pengalaman kerja bernilai nol, maka kinerja pegawai akan bernilai 1,911.

2. Koefisien variabel pendidikan sebesar 0,247, berarti jika terjadi peningkatan/penurunan variabel pendidikan satu satuan, maka kinerja perangkat desa akan meningkat/menurun sebesar 0,247.dengan asumsi variabel pelatihan dan pengalaman kerja konstan.

3. Koefisien variabel pelatihan sebesar 0,397, berarti jika terjadi peningkatan/penurunan variabel pelatihan satu satuan, maka kinerja perangkat desa akan meningkat/menurun sebesar 0,397.dengan asumsi variabel pendidikan dan pengalaman kerja konstan

4. Koefisien variabel motivasi sebesar 0,108 , berarti jika terjadi peningkatan variabel motivasi satu satuan, maka kinerja perangkat desa akan menurun sebesar 0,108. Dan jika terjadi penurunan variabel motivasi sebesar 0,108 makan kinerja perangkat desa akan meningkat sebesar 0,108.

5. Koefisien variabel pengalaman kerja sebesar 0,284, berarti jika terjadi peningkatan/penurunan variabel pengalaman kerja satu satuan, maka kinerja perangkat desa akan meningkat/menurun sebesar 0,284.dengan asumsi variabel pendidikan dan pelatihan kerja konstan.

Berdasarkan penjelasan tersebut, menunjukkan bahwa variabel pendidikan, pelatihan dan pengalaman memiliki koefisien regresi positif sedangkan variabel motivasi memiliki regresi negatif. Hal ini berarti variabel Pendidikan (X1), Pelatihan (X2) dan Pengalaman Kerja (X4) mempunyai hubungan searah atau berbanding lurus dengan variabel terikatnya sedangkan variabel Motivasi (X3) mempunyai hubungan berlawan atau berbanding terbalik dengan variabel terikatnya.

\subsubsection{Uji Hipotesis}

\section{Uji Hipotesis II : Uji t Secara} Parsial

Melalui pengujian ini akan dapat diketahui apakah variabel yang terdiri dari Pendidikan (X1), Pelatihan (X2), Motivasi (X3) dan Pengalaman Kerja (X4) berpengaruh secara parsial terhadap kinerja (Y) Perangkat Desa di Kecamatan Murung Pudak Kabupaten Tabalong, yaitu dengan membandingkan nilai probability signifikansi variabel dengan probability $5 \%$ $(\alpha=0,05)$ apabila nilai probability signifikansi $<\quad(\alpha=0,05)$ maka terdapat pengaruh signifikansi terhadap variabel terikatnya, begitu juga sebaliknya. Adapun hasil perhitungan statistik dapat dilihat pada tabel 5.15 dibawah ini :

\section{Tabel 5.15 Rekapitulasi Nilai Uji Parsial}

\begin{tabular}{|l|c|c|c|c|}
\hline $\begin{array}{l}\text { Variabel } \\
\text { bebas }\end{array}$ & $\begin{array}{c}\mathrm{t} \\
\text { hitun } \\
\mathrm{g}\end{array}$ & Sig. & $\begin{array}{c}\text { Keterang } \\
\text { an }\end{array}$ & $\begin{array}{c}\text { Signifik } \\
\text { an atau } \\
\text { tidak } \\
\text { signifik } \\
\text { an }\end{array}$ \\
\hline $\begin{array}{l}\text { X1 } \\
\text { Pendidika } \\
\mathrm{n}\end{array}$ & $\begin{array}{c}1,82 \\
0\end{array}$ & $\begin{array}{c}0,07 \\
9\end{array}$ & $\begin{array}{c}\mathrm{Sig}> \\
0,05\end{array}$ & $\begin{array}{c}\text { Tidak } \\
\text { Signifik } \\
\text { an }\end{array}$ \\
\hline $\begin{array}{l}\text { X2 } \\
\text { Pelatihan }\end{array}$ & $\begin{array}{c}1,96 \\
9\end{array}$ & $\begin{array}{c}0,05 \\
8\end{array}$ & $\begin{array}{c}\text { Sig }> \\
0,05\end{array}$ & $\begin{array}{c}\text { Tidak } \\
\text { Signifik } \\
\text { an }\end{array}$ \\
\hline $\begin{array}{l}\text { X3 } \\
\text { Motivasi }\end{array}$ & $\begin{array}{c}0,66 \\
8\end{array}$ & $\begin{array}{c}0,50 \\
9\end{array}$ & $\begin{array}{c}\text { Sig }> \\
0,05\end{array}$ & $\begin{array}{c}\text { Tidak } \\
\text { Signifik } \\
\text { an }\end{array}$ \\
\hline $\begin{array}{l}\text { X4 } \\
\text { Pengalam } \\
\text { an Kerja }\end{array}$ & $\begin{array}{c}2,10 \\
2\end{array}$ & $\begin{array}{c}0,04 \\
4\end{array}$ & $\begin{array}{c}\text { Sig }< \\
0,05\end{array}$ & $\begin{array}{c}\text { Signifik } \\
\text { an }\end{array}$ \\
\hline
\end{tabular}

Sumber : Lampiran 3

Berdasarakan tabel 5.15 dapat dilihat pengaruh variabel Pendidikan

(X1) terhadap Kinerja (Y) memiliki nilai probability signifikansi yaitu $0,079>0,05$ dan $t_{\text {hitung }} 1,820<t_{\text {tabel }} 2,042$, sehingga dapat disimpulkan bahwa Pendidikan (X1) tidak berpengaruh signifikan secara sendiri sendiri atau parsial terhadap Kinerja (Y) Perangkat Desa di Kecamatan Murung Pudak Kabupaten Tabalong.

Pengaruh variabel Pelatihan (X2) terhadap Kinerja (Y) dimana nilai probability signifikansi yaitu $0,509>0,05$ dan $t_{\text {hitung }}$ $1,969<t_{\text {tabel }} 2,042$, sehingga dapat disimpulkan bahwa Pelatihan (X1) tidak berpengaruh signifikan secara sendiri sendiri atau parsial terhadap Kinerja (Y) Perangkat Desa di Kecamatan Murung Pudak Kabupaten Tabalong.

Pengaruh variabel Motivasi (X3) terhadap Kinerja (Y) dimana nilai probability signifikansi yaitu $0,058>0,05$ dan $t_{\text {hitung }}$ $0,668<\mathrm{t}_{\text {tabel }} 2,042$, sehingga dapat disimpulkan bahwa Motivasi (X1) tidak 
berpengaruh signifikan secara sendiri sendiri atau parsial terhadap Kinerja (Y) Perangkat Desa di Kecamatan Murung Pudak Kabupaten Tabalong.

Pengaruh variabel Pengalaman Kerja (X4) terhadap Kinerja (Y) dimana nilai probability signifikansi yaitu $0,044<0,05$ dan $t_{\text {hitung }} 2,102>t_{\text {tabel }} 2,042$, sehingga dapat disimpulkan bahwa Motivasi (X1) berpengaruh signifikan secara sendiri sendiri atau parsial terhadap Kinerja (Y) Perangkat Desa di Kecamatan Murung Pudak Kabupaten Tabalong.

\section{Uji Hipotesis : Uji F Secara Simultan}

Uji ini digunakan dengan tujuan untuk membuktikan apakah variabel bebas berpengaruh secara bersama-sama terhadap variabel terikat. Dalam menjawab hipotesis yang diajukan pada awal penelitian, menggunakan alat bantu SPSS versi 23.00. dari hasil perhitungan melalui SPSS

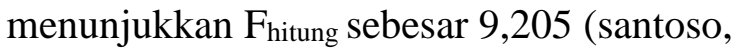
2010 : 300), apabila signifikansi $<0,05$ maka dapat disimpulkan variabel bebas berpengaruh signifikan terhadap variabel terikatnya, berdasarkan tabel 5.14 diatas, maka nilai sig $F$ hitung $0,000<0,05$ dan $F_{\text {hitung }} 9,205>F_{\text {tabel }}$ 2,900, maka secara simultan variabel Pendidikan, Pelatihan, Motivasi dan Pengalaman Kerja berpengaruh signifikan terhadap Kinerja Perangkat Desa di Kecamatan Murung Pudak Kabupaten Tabalong. Dengan demikian hipotesis ini dapat diterima atau teruji.

\section{Uji Hipotesis IV : Variabel Yang Paling Berpengaruh}

Hasil penelitian menunjukkan variabel yang berpengaruh dominan terhadap kinerja adalah pengalaman kerja (X4) karena dalam uji parsial dari keempat variabel hanya variabel pengalaman kerja (X4) yang berpengaruh secara parsial sedangkan variabel Pendidikan (X1), variabel Pelatihan (X2), dan variabel Motivasi (X3) secara parsial tidak berpengaruh terhadap variabel terikatnya. Sehingga variabel yang berpengaruh dominan adalah pengalaman. Dengan demikian hipotesis ketiga yang menyatakan bahwa pelatihan (X2) merupakan faktor yang paling berpengaruh terhadap kinerja (Y) adalah tidak terbukti.

\subsection{Pembahasan}

1. Pengaruh Pendidikan, Pelatihan, Motivasi dan Pengalaman Kerja Secara Parsial Terhadap Kinerja Perangkat Desa di Kecamatan Murung Pudak Kabupaten Tabalong.

a) Pengaruh Pendidikan Secara Parsial Terhadap Kinerja Perangkat Desa di Kecamatan Murung Pudak Kabupaten Tabalong.

Pendidikan secara parsial tidak berpengaruh terhadap Kinerja Perangkat Desa di Kecamatan Murung Pudak Kabupaten Tabalong. Berdasarkan hasil jawaban responden atas kuesioner pertanyaan variabel pendidikan dominan menjawab setuju jika Pendidikan yang saya tempuh memberikan pengetahuan tentang pekerjaan saya sekarang, Pendidikan yang saya tempuh sesuai dengan Jabatan saya sekarang ini, Melalui pendidikan, saya mendapatkan keterampilan yang bisa saya gunakan dalam melaksanakan pekerjaan, Pendidikan membuat saya bisa melakukan pekerjaan dengan baik, Pengetahuan yang dimiliki perangkat desa efektif dalam menunjang pekerjaan, Pendidikan akademis dapat meningkatkan kualitas dan kemampuan untuk mencapai kedudukan dan karir yang lebih baik.

Dari temuan penelitian Pendidikan secara parsial tidak berpengaruh terhadap Kinerja Perangkat Desa di Kecamatan Murung Pudak Kabupaten Tabalong karena signifikansi >0,05. Ini menandakan Pendidikan Perangkat Desa saat ini sudah cukup baik.

Penelitian ini dilakukan secara kuantitatif dengan jumlah responden 35 (tigapuluh lima) orang, untuk penelitian lanjutan agar bisa memperluas sampel pendidikan agar jawaban responden mengenai variabel Pendidikan lebih bervariasi lagi.

b) Pengaruh Pelatihan Secara Parsial Terhadap Kinerja Perangkat Desa di Kecamatan Murung Pudak Kabupaten Tabalong.

Pelatihan secara parsial tidak berpengaruh 
terhadap Kinerja Perangkat Desa di Kecamatan Murung Pudak Kabupaten Tabalong. Berdasarkan hasil jawaban responden atas kuesioner pertanyaan variabel Pelatihan dominan menjawab setuju jika Pelatihan yang telah dikuti selama ini mendukung tugas saya selaku perangkat desa, Materi pelatihan sesuai kebutuhan dengan pengetahuan yang ingin saya peroleh dalam menjalankan tugas selaku perangkat desa, Pelatih/Instruktur dapat menyampaikan materi dengan jelas dan mudah dipahami, saya berpasrtisipasi aktif dalam pelaksanaan program pelatihan, Setelah mengikuti pelatihan, saya menjadi lebih memahami tanggung jawab saya, Setelah mengikuti pelatihan, saya dapat meningkatkan kinerja saya

Dari temuan Pelatihan secara parsial tidak berpengaruh terhadap Kinerja Perangkat Desa di Kecamatan Murung Pudak Kabupaten Tabalong karena signifikansi > 0,05. Ini menandakan Pelatihan Perangkat Desa saat ini sudah cukup baik.

Penelitian ini dilakukan secara kuantitatif dengan jumlah responden 35 (tigapuluh lima) orang, untuk penelitian lanjutan agar bisa memperluas sampel Pelatihan agar jawaban responden mengenai variabel Pelatihan lebih bervariasi lagi.

c) Pengaruh Motivasi Secara Parsial Terhadap Kinerja Perangkat Desa di Kecamatan Murung Pudak Kabupaten Tabalong.

Motivasi secara parsial tidak berpengaruh terhadap Kinerja Perangkat Desa di Kecamatan Murung Pudak Kabupaten Tabalong. Berdasarkan hasil jawaban responden atas kuesioner pertanyaan variabel Motivasi dominan menjawab setuju jika Saya mendapatkan jaminan kesehatan selama bekerja, Gaji dan Insentif yang saya terima sesuai dengan beban kerja, Atasan dan rekan kerja ditempat kerja peduli dengan saya, Pimpinan memberikan kesempatan kepada saya untuk memberikan ide-ide kreatif dalam bekerja, Saya mendapatkan rasa aman dan keselamatan kerja, Saya dapat mengembangkan kreatifivitas dalam bekerja.

Dari temuan Motivasi secara parsial tidak berpengaruh terhadap Kinerja Perangkat
Desa di Kecamatan Murung Pudak Kabupaten Tabalong karena signifikansi > 0,05. Ini menandakan Motivasi Perangkat Desa saat ini sudah cukup baik.

Penelitian ini dilakukan secara kuantitatif dengan jumlah responden 35 (tigapuluh lima) orang, untuk penelitian lanjutan agar bisa memperluas sampel Motivasi agar jawaban responden mengenai variabel Motivasi lebih bervariasi lagi.

d) Pengaruh Pengalaman Kerja Secara Parsial Terhadap Kinerja Perangkat Desa di Kecamatan Murung Pudak Kabupaten Tabalong.

Pengalaman Kerja secara parsial berpengaruh terhadap Kinerja Perangkat Desa di Kecamatan Murung Pudak Kabupaten Tabalong. Pengalaman Kerja sangat membantu perangkat desa dalam melaksanakan tugas-tugas pemerintahan desa.

Berdasarkan hasil jawaban responden atas kuesioner pertanyaan variabel Pengalaman Kerja dominan menjawab setuju jika Masa kerja yang dimiliki sangat membantu tugas dan pekerjaan saya sebagai Perangkat Desa, keberhasilan dalam menjalankan tugas sebagai Perangkat desa sangat didukung oleh pengalaman saya sebagai aparatur pemerintah, Pengalaman kerja yang saya miliki, membantu mengurangi kesalahankesalahan saya saat bekerja, Pengalaman kerja yang saya miliki, membantu saya menguasai pekerjaan yang diberikan, Pengalaman bekerja sebelumnya mampu menambah pengalaman saya untuk bekerja sebagai perangkat desa, Pengalaman kerja yang saya miliki berperan penting dalam melaksanakan tugas yang diberikan oleh pemerintah desa, Pengalaman kerja yang saya miliki memberikan kemampuan penilaian dan penganalisaan pekerjaan yang diberikan oleh pemerintah desa.

Dari temuan Pengalaman Kerja secara parsial berpengaruh terhadap Kinerja Perangkat Desa di Kecamatan Murung Pudak Kabupaten Tabalong karena signifikansi $<0,05$. Untuk itu Pemerintah Desa perlu selalu memberikan dukungan perangkat desa yang ada karena memiliki pengalaman yang memadai.

Penelitian ini dilakukan secara kuantitatif 
dengan jumlah responden 35 (tigapuluh lima) orang, untuk penelitian lanjutan agar bisa memperluas sampel Motivasi agar jawaban responden mengenai variabel Motivasi lebih bervariasi lagi.

2. Pengaruh Pendidikan, Pelatihan, Motivasi dan Pengalaman Kerja Secara Simultan Terhadap Kinerja Perangkat Desa di Kecamatan Murung Pudak Kabupaten Tabalong.

Pendidikan, Pelatihan, Motivasi dan Pengalaman Kerja Secara Simultan Terhadap Kinerja Perangkat Desa di Kecamatan Murung Pudak Kabupaten Tabalong, perangkat desa akan menjadi baik dalam bekerja jika mendapat pendidikan sesuai dengan bidang pekerjaannya selain itu pelatihan juga perlu diberikan secara berkala agar perkembangan ilmu pemerintahan desa dapat terus didapat. Dan perangkat desa harus selalu diberikan motivasi untuk mendukung pengalaman kerja yang ada dalam melaksanakan pekerjaan sesuai dengan hasil yang dicapainya.

Temuan ini sejalan dengan hasil penelitian yang dilakukan, dimana nilai koefisien determinasi (R2) diperoleh sebesar 0,551. Angka ini menunjukkan bahwa kemampuan variabel bebas (Pendidikan, Pelatihan, Motivasi dan Pengalaman Kerja) menjelaskan pengaruhnya terhadap variabel terikat (kinerja perangkat desa) sebesar $55,10 \%$.

Penelitian ini dilakukan secara kuantitati dengan jumlah sampel 35 (tigapuluh lima) orang, untuk penelitian lanjutan agar memperluas sampel penelitian agar jawaban responden mengenai varibael Pendidikan, Pelatihan, Motivasi, Pengalaman Kerja dan Kinerja lebih bervariasi lagi.

\section{Variabel yang berpengaruh} dominan terhadap Kinerja Perangkat Desa di Kecamatan Murung Pudak Kabupaten Tabalong.

Hasil penelitian menunjukkan bahwa variabel yag dominan berpengaruh terhadap Kinerja Perangkat Desa di Kecamatan Murung Pudak Kabupaten Tabalong adalah
Pengalaman Kerja. Pengalaman kerja memiliki pengaruh yang sangat besar terhadap perangkat desa. Hal itulah yang menyebabkan kenapa variabel lain tidak berpengaruh dominan terhadap variabel kinerja.

Pengalaman kerja merupakan variabel yang berpengaruh dominan terhadap Kinerja Perangkat Desa di Kecamatan Murung Pudak Kabupaten Tabalong karena dari hasil penelitian menunjukkan hanya variabel pengalaman kerja yang berpengaruh secara parsial terhadap variabel kinerja sedangkan variabel pendidikan, pelatihan dan motivasi tidak berpengaruh terhadap variabel terikatnya.

Berdasarkan hasil penelitian dan analisa yang telah dilakukan maka hasil pembahasan dari penelitian ini dapat disimpulkan sebagai berikut :

a. Faktor variabel bebas (independent) yaitu variabel Pendidikan (X1), Pelatihan (X2), Variabel Motivasi (X3), Variabel Pengalaman Kerja (X4), bahwa keempat variabel tersebut berpengaruh terhadap variabel terikat (dependent) yaitu variabel Kinerja (Y) Perangkat Desa di Kecamatan Murung Pudak Kabupaten Tabalong terbukti dengan tanggapan responden yang dilakukan pada dasarnya jawaban responden lebih banyak dengan jawaban setuju.

b. Semua indikator dari penelitian ini dinyatakan sahih terbukti dengan Rekapitulasi daftar nilai Pearson Corelation pada penelitian semua indikator variabel menyatakan valid, begitu pula dengan rekapitulasi daftar nilai Alpha Cronbach semua indikator menyatakan Reliabel.

c. Dari keempat variabel independent (bebas) hanya satu variabel yang berpengaruh secara parsial pada variabel dependent (terikat) yaitu variabel Pengalaman Kerja (X4) terbukti dengan nilai t-hitung variabel lebih besar dari t-tabel yang didapat dari jumlah responden sebanyak 35 orang dengan perhitungan memakai 4 indikator bebas dan 1 indikator terikat dengan taraf kepecayaan sebesar $0,05 \%$ maka didapat nilai t-tabel adalah 2,042 lebih kecil dari nilai t-hitung sedangkan ada tiga variabel tidak berpengaruh secara 
parsial terhadap variabel dependent (terikat) yaitu variabel Pendidikan (X1), variabel Pelatihan (X2) dan variabel Motivasi (X4), terbukti dengan nilai masing-masing setiap variabel lebih kecil dari t-tabel yang didapat dari jumlah responden sebanyak 35 orang dengan perhitungan memakai 4 indikator bebas dan 1 indikator terikat dengan taraf kepercayaan sebesar $0,05 \%$ maka didapat nilai t-tabel adalah 2,042 lebih besar dari semua nilai t-hitung setiap variabel yaitu :

Nilai t-hitung variabel Pengalaman Kerja (X1) 2,102 lebih besar dari t-tabel 2,042

- Nilai t-hitung variabel Pendidikan (X1) 1,820 lebih kecil dari $t_{\text {tabel }} 2,042$

- $\quad$ Nilai t-hitung variabel Pelatihan (X2) 1,969 lebih kecil dari t-tabel 2,042

- $\quad$ Nilai t-hitung variabel Motivasi (X3) 0,668 lebih kecil dari $t_{\text {-tabel }} 2,042$

d. Keempat variabel independent (bebas) tersebut secara simultan berpengaruh terhadap variabel dependent (terikat) ini terbukti dengan nilai $\mathrm{F}_{\text {-hitung }}$ lebih besar dari nilai $\mathrm{F}_{\text {-tabel }}$ yang didapat dari perhitungan memakai respoden sebanyak 35 orang dengan memakai 4 indikator bebas dan 1 indikator terikat dengan taraf kepercayaan sebesar $0,05 \%$ maka didapat nilai $\mathrm{F}_{\text {-tabel }}$ sebesar 2,900 lebih kecil dari $\mathrm{F}_{\text {- }}$ hitung sebesar 9,205 sehingga kesimpulan hipotesis diterima.

e. Variable Motivasi (X3) memiliki koefisien regresi negatif yaitu mempunyai hubungan yang berlawanan atau berbanding terbalik dengan variabel Kinerja (Y). Hal ini disebabkan karena perangkat desa merasa nyaman dengan motivasi yang ada, mereka beranggapan bahwa adanya peningkatan motivasi akan membuat mereka diminta meningkatkan kinerjanya. Oleh karena itu hasil koefisien regresinya menjadi negatif.

f. Dari keempat variabel independent (bebas) yaitu variabel Pendidikan (X1), variabel Pelatihan (X2), variabel Motivasi (X3) dan variabel Pengalaman Kerja (X4) yang paling dominan berpengaruh terhadap Variabel Kinerja (Y) adalah variabel Pengalaman Kerja (X4), terbukti dengan nilai hasil uji secara parsial dimana satusatunya variabel yang memiliki pengaruh terhadap variabel terikatnya.

\section{KESIMPULAN}

Dari hasil penelitian dapat ditarik beberapa kesimpulan sebagai berikut :

1. Dari hasil penelitian telah terlihat bawa dari keempat variabel hanya satu variabel yaitu variabel Pengalaman Kerja (X4) yang berpengaruh signifikan terhadap Kinerja (Y) Perangkat Desa di Kecamatan Murung Pudak Kabupaten Tabalong secara parsial. Sedangkan tiga variabel lainnya yaitu variabel Pendidikan (X1), Pelatihan (X2) dan Motivasi (X3) tidak berpengaruh signifikan terhadap Kinerja (Y) Perangkat Desa di Kecamatan Murung Pudak Kabupaten Tabalong secara parsial.

2. Keempat variabel independent secara simultan berpengaruh signifikan terhadap Kinerja.

3. Hasil penelitian menyatakan bahwa variabel yang berpengaruh dominan terhadap Kinerja adalah variabel Pengalaman Kerja (X4).

\section{DAFTAR PUSTAKA}

Arikunto, S. 2006. Metode Penelitian Kualitatif. Jakarta: Bumi Aksara

As'ad, M. 2001. Seri Ilmu Sumber Daya Manusia : Psikologi Industri, Edisi Keempat, Cetakan Keenam, Penerbit Liberty, Yogyakarta.

Atmosoeprapto, Krisdarto. 2004. Kiat : Drives Your Vision to Tactical Action (Mewujudkan Visi \& Misi Dalam Tindak Nyata), Penerbit Elex Media Komputindo, Jakarta.

Bungin, Burhan. 2005. Metodologi Penelitian Kuantitatif, Edisi Pertama, Cetakan Kedua, Penerbit Kencana, Jakarta. Cushway, Barry dan Lodge. 2001. Human Resources Management, (Tract MBA Series/Terjemahan), Penerbit PT. Gramedia Pustaka Utama, Jakarta.

Dharma, Surya. 2007. Manajemen Kinerja: Falsafah Teori dan Penerapannya, Penerbit Pustaka Pelajar, Yogyakarta.

Flippo, Edwin B. 1996. Personnel Management, Sixth Edition, McGraw-Hill Inc., Singapore. 
Gomes, Faustino Cardoso. 2000. Manajemen Sumber Daya Manusia, Edisi Kedua, Cetakan Ketiga, Penerbit Andi Offset, Yogyakarta.

Hamalik, Oemar. 2006. Psikologi Manajemen : Penuntun Bagi Pemimpin, Cetakan Ketiga, Penerbit Trigenda Karya, Bandung.

Handoko, T. Hani. 2005. Manajemen Personalia dan Sumber Daya Manusia, Edisi Keempat, BPFE, Yogyakarta.

Hasibuan, Malayu S.P. 2000. Manajemen Sumber Daya Manusia, Penerbit Bumi Aksara, Jakarta.

Indrawijaya, Adam, 2003. Perilaku Organisasi, Penerbit Sinar Baru, Bandung. Kuncoro, Mudrajad. 2003. Metode Riset Untuk Bisnis \& Ekonomi, Penerbit Erlangga, Jakarta.

Luthans, Freud. 2001. Organizational Behavioral, Seventh Edition, McGrawHill Inc., New York.

Mangkunegara, A.A. Anwar Prabu. 2007. Evaluasi Kinerja SDM, Cetakan Ketiga, Penerbit PT. Refika Aditama, Bandun 2006. Perencanaan dan Pengembangan Sumber Daya Manusia, Cetakan Kedua, Penerbit PT. Refika Aditama, Bandung.

Nawawi, Hadari. 2006. Manajemen Sumber Daya Manusia Untuk Bisnis yang Kompetitif, BPFE, Yogyakarta.

Nazir, Moh. 2003. Metode Penelitian, Cetakan Kelima, Penerbit Ghalia Indonesia, Jakarta.

Notoatmojo, $\quad$ Soekidjo. 2003. Pengembangan Sumber Daya Manusia, Edisi Revisi, Penerbit Rineka Cipta, Jakarta.

Rivai, Veithzal. 2005. Performance Appraisal, Edisi Pertama, Penerbit PT. RajaGrafindo Persada, Jakarta. 2006. Manajemen Sumber Daya Manusia, Edisi Pertama, Penerbit PT. RajaGrafindo Persada, Jakarta.

Ruky, Achmad S. 2003. Sumber Daya Manusia Berkualitas Mengubah Visi Menjadi Realitas, Penerbit PT. Gramedia Pustaka Utama, Jakarta.

Saydam, Gouzali. 2004. Manajemen Sumber Daya Manusia, Penerbit PT Elex Media Komputindo, Jakarta.
Sedarmayanti. 2005. Manajemen Sumber Daya Manusia, Penerbit PT. Refika Aditama, Bandung.

Siagian, Sondang P. 2002. Manajemen

Sumber Daya Manusia, Penerbit Bumi Aksara, Jakarta.

Simamora, Henry. 2004. Manajemen Sumber Daya Manusia, Edisi Ketiga, Cetakan Pertama, Penerbit STIE YKPN, Yogyakarta.

Sugiyono. 2010. Metode Penelitian Pendidikan Pendekatan Kuantitatif, kualitatif, dan R\&D. Bandung: Alfabeta.

Soeprihanto, Jhon. 2001. Penilaian Kinerja dan Pengembangan Karyawan, Edisi Pertama, Cetakan Kelima, BPFE, Yogyakarta.

Timpe, Werther. 2005. Human Resources and Personnel Management, McGrawHill Book Company, New York.

Umar, Husein. 2007. Riset Sumber Daya Manusia Dalam Organisasi, Cetakan Ketujuh, Penerbit PT. Gramedia Pustaka Utama, Jakarta. 2001. Metode Penelitian Untuk Skripsi dan Tesis Bisnis, Edisi Baru, Cetakan Keempat, Penerbit PT. RajaGrafindo Persada, Jakarta.

Wahjosumidjo. 2004. Manajemen Sumber Daya Manusia, Penerbit Bumi Aksara, Jakarta.

Wibowo, 2007. Manajemen Kinerja, Edisi Pertama, Penerbit PT. RajaGrafindo Persada, Jakarta.

Wursanto, 1989. Paradigma Manajemen Sumber Daya Manusia, Penerbit Amara Books, Yogyakarta.

Zainun, Ahmad. 2005. Manajemen Sumber Daya Manusia, Edisi Pertama, Cetakan Pertama, Penerbit STIE YKPN, Yogyakarta.

Ahdhianto, Erif, Download SPSS 23 http://pendidikandasar.com (diakses tanggal 27 Oktober 2019).

SPSS Indonesia, Olah Data Statistik dengan SPSS https://www.spssindonesia.com/ (diakses tanggal 12 Februari 2020) 